\title{
PEMBERDAYAAN UMKM PEREMPUAN KOTA DENPASAR DIBIDANG E-COMMERCE
}

\author{
Linawati $^{1}$, N.M.A.E.D. Wirastuti ${ }^{2}$, I.M.O. Widyantara ${ }^{3}$, D.M. Wiharta ${ }^{4}$, \\ P.A. Mertasana ${ }^{5}$
}

\begin{abstract}
ABSTRAK
Sektor UMKM di Indonesia khususnya di Denpasar - Bali membutuhkan inovasi khususnya dalam bidang teknologi informasi komunikasi (TIK). Kemajuan TIK dapat membantu perekonomian Indonesia yaitu ecommerce dalam bentuk toko online atau pasar online yang memudahkan UMKM khususnya pengusaha perempuan. Pengusaha UMKM perempuan masih terbatas menjalankan bisnis dalam bentuk e-commerce. Salah satu cara untuk meningkatkan pemanfaatan e-commerce dikalangan pengusaha UMKM Perempuan adalah melalui pelatihan e-commerce, khususnya untuk Kota Denpasar. Kegiatan ini berjalan $\mathrm{n}$ baik berkat kerjasama dengan Badan Pemberdayaan Perempuan dan Anak, Dinas Pemberdayaan Perempuan dan Perlindungan Anak, Pengendalian Penduduk dan Keluarga Berencana, Pemerintah Kota Denpasar. Mayoritas peserta menyatakan kepuasannya dan pemahaman mereka tentang e-commerce. Akhirnya kegiatan ini juga meningkatkan kapasitas perempuan dibidang perekonomian online, dimana hasil evaluasi menyatakan lebih dari $70 \%$ dari total peserta menyatakan pelatihan ini sangat efektif dan seluruh peserta tertarik untuk mengimplementasikannya setelah pelatihan.
\end{abstract}

Kata Kunci: UMKM, perempuan, e-commerce.

\begin{abstract}
Micro, Small, Medium Enterprise (MSME) in Indonesia, especially MSME business women in Denpasar - Bali needs innovation using information communicaton technology to expand their business. Then the enterprise can be transformed to be e-commerce. Thus, e-commerce workshop has been designet and implemented for MSME business women in Denpasar City in collaboration with Department of Women and Children empowerment, Denpasar City. From the workshop evaluation results, most of participants were satisfied and their understanding with e-commerce was increased. As a result, the workshop increases their capacity building as a MSME business woman in term of e-commerce. This is shown by their statements that more than $70 \%$ of total participant approved the workshop was very effective, and they eager to implement it in their business.
\end{abstract}

Keywords: MSME, women, e-commerce.

\section{PENDAHULUAN}

Situasi ekonomi Indonesia saat ini masih banyak yang perlu dibenahi. Hal ini dapat dikarenakan masih terbatasnya fasilitas-fasilitas yang memadai khususnya dalam bidang perdagangan dan bisnis di Indonesia, termasuk sektor usaha mikro, kecil dan menengah (UMKM). Kontribusi sektor UMKM terhadap produk domestik bruto (PDB) semakin menggeliat dalam lima tahun terakhir. Kementerian Koperasi dan Usaha Kecil Menengah (UKM) mencatat kontribusi sektor UMKM meningkat dari

1,2,3,4,5 Jurusan Teknik Elektro Fakultas Teknik Universitas Udayana, Email: linawati@unud.ac.id 
57,84 persen menjadi 60,34 persen. Tak hanya itu, sektor UMKM juga telah membantu penyerapan tenaga kerja di dalam negeri. Serapan tenaga kerja pada sektor UMKM tumbuh dari 96,99 persen menjadi 97,22 persen dalam periode lima tahun terakhir (CNN Indonesia, 2016).

UMKM di Indonesia membutuhkan sebuah inovasi baik dalam bidang teknologi maupun nonteknologi yang dapat memfasilitasi mereka dalam proses jual beli produk atau jasa mereka. Dewasa ini perkembangan teknologi semakin berkembang pesat. Perkembangan teknologi yang semakin pesat ini diharapkan mampu membantu jalannya perkenomian di Indonesia. UMKM merupakan tulang punggung perekonomian Indonesia membutuhkan pengenalan teknologi serta pengaplikasian teknologi dalam bidang perdagangan dan bisnis.

Oleh sebab itu, salah satu contoh kemajuan teknologi yang dapat membantu jalannya perekonomian Indonesia saat ini yaitu fasilitas toko online (tokopedia, 2017), (mataharimall, 2017), (bhinneka, 2017), (bukalapak, 2017), (lazada, 2017), (shopee, 2017), (blibli, 2017), (zalora, 2017). Fasilitas toko online dapat memudahkan anggota UMKM dalam proses jual beli produk atau jasa yang dimiliki sehingga modal yang diperlukan menjadi sedikit karena tidak memerlukan gedung atau toko fisik serta kelengkapan toko lain seperti rak dan meja serta pegawai untuk mengurus toko. Selain itu, jangkauan pemasaran produk dan jasa yang dimiliki menjadi lebih luas karena fasilitas toko online ini menggunakan internet sehingga dapat diakses semua orang di manapun mereka berada. Transaksi online ini dimudahkan dengan fasilitas pendukung seperti layanan perbankan online (BNI, 2017) dan jasa pengiriman atau antar - jemput (Go-Jek, 2017), (Grab, 2017). Keamanan transaksi serta etika dalam transaksi online pun terus dikembangkan untuk mendukung e-commerce ini (Internetsociety, 2017), (isoc, 2017). Sektor UMKM juga banyak digerakkan oleh perempuan, dimana mereka ingin membantu perekonomian keluarga namun tetap bisa melakukan pekerjaan rumah tangga (Ekonomi, Kompas, 2017). Perempuan Indonesia memegang peranan penting dalam menopang kesejahteraan keluarga, sehingga peranan perempuan di sektor UMKM perlu ditingkatkan. Salah satu strategi adalah memberikan pelatihan e-commerce pada perempuan Kota Denpasar. Kemudian pelatihan ini dievaluasi efektivitasnya melalui analisis hasil kuesioner yang diisi oleh peserta.

Sesuai dengan Undang- Undang Nomor 20 Tahun 2008 tentang Usaha Mikro, Kecil dan Menengah (BUMN, 2015), maka usaha mikro adalah usaha produktif dengan aset maksimum Rp 50 juta dan omzet maksimum Rp 300 juta. Sedangkan Usaha Kecil adalah usaha ekonomi produktif yang berdiri sendiri dengan aset mulai Rp 50 juta sampai dengan Rp 500 juta, dan omzet dari Rp 300 juta sampai dengan Rp 2,5 miliar. Usaha Menengah adalah usaha ekonomi produktif dengan jumlah kekayaan bersih atau hasil penjualan tahunan, dengan aset mulai dari Rp 500 juta sampai dengan Rp 10 miliar, dan omzet dari Rp 2,5 miliar sampai dengan Rp 50 miliar.

UMKM juga merupakan pelaku ekonomi yang penting dalam menyerap tenaga kerja di ASEAN (BI, 2016). Namun kinerja UMKM Indonesia masih relatif rendah dibandingkan negara-negara ASEAN terutama dari segi produktivitas, kontribusi ekspor, partisipasi untuk produksi global dan regional serta kontribusi terhadap nilai tambah. Beberapa studi menyatakan faktor yang mempengaruhi kemampuan UMKM adalah tergantung dari faktor internal yang mempengaruhi produktivitas dan inovasi perusahaan serta faktor eksternal, keterbatasan sumber daya seperti keuangan, informasi, kapasitas manajemen dan teknologi serta akses terhadap informasi pasar. Faktor yang mampu meningkatkan partisipasi UMKM dalam perekonomian global adalah skala dan kematangan usaha, foreign linkage, produktivitas, inovasi dan akses pembiayaan. Khusus untuk rendahnya partisipasi Indonesia disebabkan oleh belum optimalnya infrastruktur dan penggunaan teknologi komunikasi informasi, kehandalan dan efisiensi jasa logistik, tingginya hambatan perdagangan, tingkat upah yang relatif tinggi dibandingkan negara ASEAN serta ketatnya persyaratan dalam akses pembiayaan perbankan. Selain itu, pelaku usaha di Indonesia mengalami kesulitan memenuhi standar produk internasional karena adanya kesulitan perolehan bahan baku lokal yang sesuai dengan permintaan konsumen global. Sehingga secara spesifik, beberapa hal yang perlu dibenahi untuk meningkatkan daya saing UMKM Indonesia adalah: Produktivitas dan Inovasi, Kemudahan Berusaha

\section{4 | BULETIN UDAYANA MENGABDI}


(Ease of Doing Business), Akses Permodalan (Access to Finance), Akses Pasar, Dukungan Infrastruktur, dan Siklus Bisnis.

Penggunaan teknologi informasi komunikasi untuk UMKM akan menjadikan UMKM sebagai pelaku e-commerce. Ada pun e-commerce adalah transaksi dan perdagangan barang dan jasa melalui media elektronik seperti Internet yang pertama kali dikenalkan pada tahun 1960-an dengan adanya perangkat electronic data interchange (EDI) pada value-added networks (VANs) [Rivera, 2017]. Dengan meningkatnya kapasitas Internet, maka penjualan online semakin popular pada awal tahun 2000-an dengan ditandai beroperasinya Amazon pada tahun 1995. Selanjutnya EBay memudahkan konsumen untuk menjual produknya secara online. Konsumen pada EBay sekaligus berfungsi sebagai penjual maupun pembeli. Pada tahun 1995 dimunculkan juga pelelangan online. Seiring dengan munculnya media sosial, maka e-commerce pun dilakukan melalui Facebook dan Instagram dengan menggunakan smartphone. E-commerce bisa digolongkan kedalam empat katagori utama yaitu B2B (business to business), B2C (business to consumer), C2B (consumer to business), dan $\mathrm{C} 2 \mathrm{C}$ (consumer to consumer).

UMKM merupakan industri yang tetap bertahan pada saat suatu negara mengalami krisis ekonomi. Untuk itu Indonesia melalui kementerian Koperasi dan UKM terus mendorong tumbuhnya UMKM baru. Kementerian Koperasi dan UKM mencatat ada 52 juta pelaku UKM (tahun 2015) [Ekonomi, Kompas, 2017]. Dari jumlah itu, 60 persennya dijalankan oleh perempuan. Pemerintah berusaha meningkatkan kapasitas UMKM tersebut. Salah satunya adalah mendigitalisasikan UMKM. Perempuan sebagai pengusaha UMKM telah membuktikan sebagai pengusaha tangguh. Hal ini terbukti dengan dikirimnya enam perempuan pengusaha UMKM untuk pameran di New York [Sulistyowati, 2017]. Keenam perempuan muda pengusaha mikro di Bali tersebut lolos berpameran di New York, Amerika Serikat, selama dua bulan. Google pun memberikan perhatian terhadap pengusaha UMKM perempuan. Data dari Google Indonesia menyatakan bahwa 80\% pegiat usaha termasuk UKM dan UMKM berhasil dengan pola pemasaran online [Oetomo, 2017]. Namun khusus pelaku UKM dan UMKM perempuan di Indonesia tidak lebih dari 50\% yang menggunakan pola digital dalam proses dagang maupun pengenalan produk. Khusus pada usaha mikro, 53\% usaha tersebut dimiliki oleh perempuan, sementara kalau dilihat dari sisi yang medium size terjadi penurunan menjadi $34 \%$. Kalau dari sisi penggunaan teknologi, maka $47 \%$ perempuan belum menggunakan teknologi secara optimal untuk bisnisnya.

\section{METODE PELAKSANAAN}

Kota Denpasar merupakan ibu kota Provinsi Bali juga sangat menaruh perhatian terhadap pemberdayaan perempuan dengan mendorong perempuan pengusaha UMKM melakukan bisnis usahanya secara online. Untuk itu dilakukan pelatihan bagaimana melakukan bisnis online. Kegiatan pelatihan ini dilaksanakan bekerja sama dengan Pemerintah Kota Denpasar, tepatnya BPPA (Badan Pemberdayaan Perempuan dan dan Anak) Dinas Pemberdayaan Perempuan dan Perlindungan Anak, Pengendalian Penduduk dan Keluarga Berencana. Kegiatan dilaksanakan dua hari yaitu tanggal 7 September dan 8 September 2017 Berikut gambar 1 menampilkan mekanisme kerja sama kegiatan. 


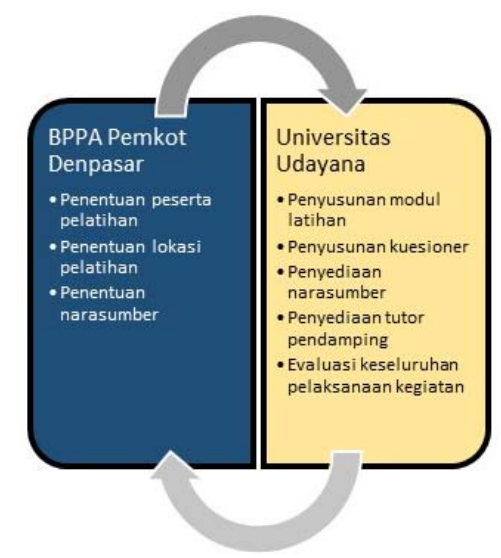

Gambar 1. Mekanisme Kerjasama Pelaksanaan Kegiatan

Tahap awal dari kegiatan ini adalah penyusunan modul dan penyusunan perangkat kuesioner. Terdapat beberapa modul yang diberikan kepada peserta sebagai berikut.

a) Pemahaman Internet, Etika, dan Keamanan

b) Transaksi Online pada situs - situs e-commerce

c) Panduan Keamanan ecommerce

d) Sistem Jualan dan Belanja Pada Toko Online

Evaluasi kegiatan dilakukan berdasarkan analisis hasil kuesioner yang diisi oleh peserta pelatihan. Kuesioner disusun secara singkat dan dengan bahasa yang mudah dipahami oleh peserta. Kuesioner dibagikan sebelum pelatihan untuk mengetahui tingkat pemahaman awal peserta tentang e-commerce dan kuesioner berikutnya dibagikan setelah pelatihan di hari pertama dan setelah pelatihan di hari kedua.

Kuesioner pertama terdiri dari 11 pertanyaan yang bisa dikatagorikan kedalam dua kelompok. Kelompok 1 menanyakan tentang identitas peserta kecuali nama dan alamat, yaitu jenis kelamin, umur, dan pekerjaan. Kelompok 2 menanyakan tentang pemahaman dasar Internet dan e-commerce. Kuesioner kedua terdiri dari 15 pertanyaan. Seperti kuesioner 1, kuesioner 2 disusun menjadi dua kelompok pertanyaan atau pernyataan. Kelompok pertanyaan atau pernyataan 1 tentang identitas peserta yaitu jenis kelamin, umur, dan pekerjaan. Kelompok pertanyaan / pernyataan 2 tentang kualitas materi, cara penyajian, kualitas penyaji / narasumber, fasilitas pelatihan, dan pemahaman peserta yang mampu meningkatkan ketertarikan peserta akan pelatihan maupun e-commerce.

\section{HASIL DAN PEMBAHASAN}

Pada hari I, sesi ke - 1 pelatihan diikuti oleh 34 peserta yang terdiri dari 32 peserta perempuan dan 2 orang peserta pria. Total kuesioner awal sebelum pelatihan diisi oleh 34 peserta. Namun pada saat sesi ke -2 , total peserta adalah 25 orang dan seluruhnya adalah peserta perempuan. Sehingga total kuesioner pada akhir pelatihan hari ke -1 diisi oleh 25 peserta perempuan. Hari ke -2 pelatihan diikuti oleh total 19 peserta yang terdiri dari 2 peserta pria dan 17 peserta perempuan. Keseluruhan peserta yang datang pada hari ke -2 ini merupakan peserta yang datang pada hari ke -1 pelatihan. Suasana pelatihan diperlihatkan pada gambar 2 . 

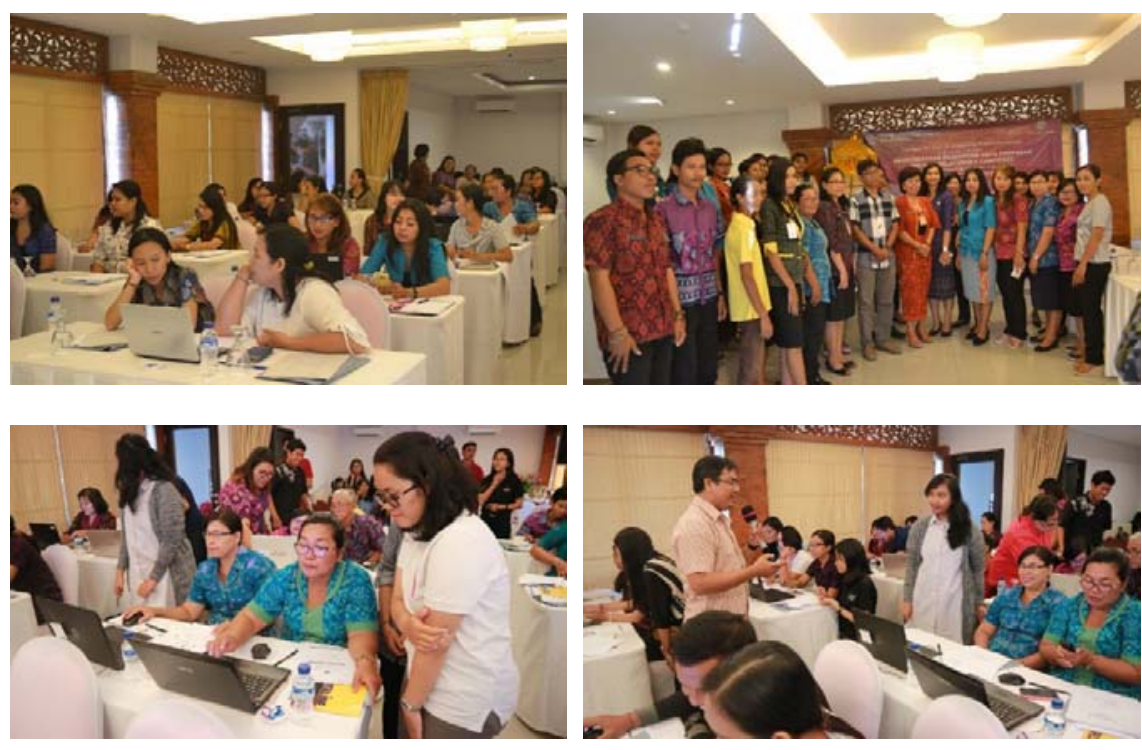

Gambar 2. Suasana Pelatihan dan Diskusi

\subsection{Pemahaman Awal Peserta Tentang E-Commerce}

Pada hari I jumlah peserta yang mengisi kuesioner adalah 34 orang yang terdiri dari 32 peserta perempuan dan 2 orang peserta pria. Terdapat peserta pria pada pelatihan ini disebabkan adanya penyampaian informasi yang tidak jelas di tingkat desa. Selanjutnya analisis kegiatan pelatihan ini akan difokuskan hanya pada peserta perempuan. Gambar 3 memperlihatkan komposisi peserta perempuan, yang mana $75 \%$ didominasi oleh usia 31 tahun ke atas. Hal ini menandakan bahwa peserta yang ikut pelatihan adalah kelompok usia dewasa yang sudah bekerja. Namun kalau dilihat dari jenis pekerjaan dari peserta perempuan pada gambar 4 , dimana $44 \%$ adalah karyawan, maka target peserta UMKM belum mencapai sasaran.

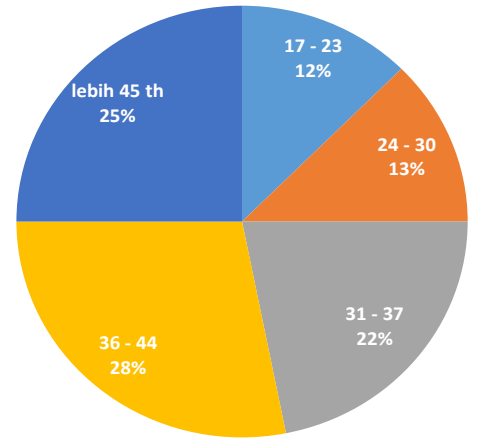

Gambar 3. Komposisi Usia Peserta Pelatihan

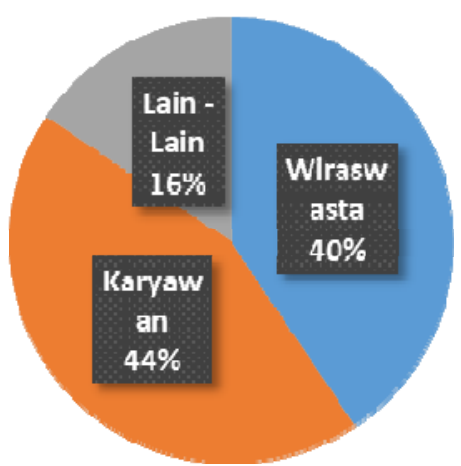

Gambar 4. Pekerjaan Peserta Perempuan

Menariknya gambar 5 sampai dengan gambar 7 menampilkan komposisi peserta perempuan yang pernah menggunakan Internet adalah $84 \%$, dan $81 \%$ mengetahui situs e-commerce seperti tokopedia, namun $97 \%$ memiliki akun media sosial. Hal ini bisa terjadi karena mereka tidak mengetahui kalau akun media sosial tersebut memerlukan keberadaan Internet. Sehingga peserta perlu diberikan pemahaman bahwa media sosial dan situs e-commerce beroperasi pada jaringan Internet. Sebagian besar peserta yaitu lebih dari 50\% pernah melakukan transaksi jual beli melalui media sosial atau situs e-commerce, seperti diperlihatkan oleh gambar 8 dan gambar 9. Ini membuktikan bahwa peserta 
sudah kenal dengan keberadaan e-commerce. Sehingga pelatihan yang diberikan akan lebih cepat bisa dipahami.

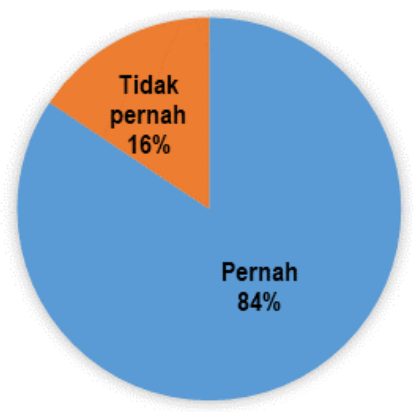

Gambar 5. Peserta Pengguna Internet

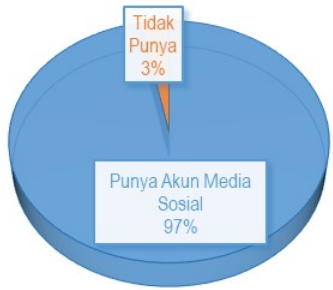

Gambar 7. Peserta yang memiliki Akun Media Sosial

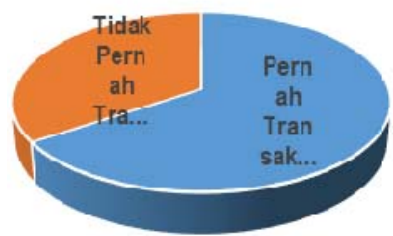

Gambar 8. Peserta yang Pernah Melakukan Transaksi Pembelian Online (melalui Media Sosial atau Situs ECommerce)

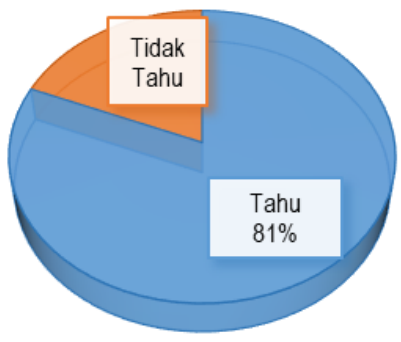

Gambar 6. Peserta yang Tahu Situs ECommerce

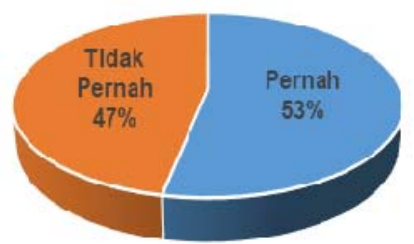

Gambar 9. Peserta yang Pernah memasarkan produk secara online (melalui media sosial atau e-commerce)

\subsection{Pemahaman Peserta Setelah Pelatihan}

Gambar 10 dan dikuatkan oleh gambar 11 menyatakan bahwa baik materi pelatihan dan kualitas pengajarannya lebih dari $90 \%$ menyatakan baik. Selanjutnya didukung oleh hasil kuesioner yang ditampilkan oleh gambar 12 yang menampilkan bahwa $82 \%$ dari total peserta menyatakan kinerja penyelenggara pelatihan baik, bahkan $60 \%$ menyatakan sangat baik. Sehingga tingkat pemahaman peserta menjadi tinggi yaitu lebih dari 50\% menyatakan tingkat pemahaman peserta melebihi $75 \%$, seperti ditampilkan oleh gambar 13. Gambar 14 pun menampilkan hasil yang relevan dengan hasil sebelumnya yaitu $92 \%$ dari total peserta menyatakan pelatihan ini efektif dan sangat efektif. Akhirnya pada pertanyaan terakhir kuesioner, seluruh peserta menyatakan tertarik untuk mengimplementasikan hasil pelatihan.

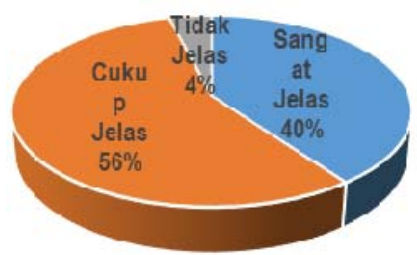

Gambar 10. Kualitas Materi Pelatihan

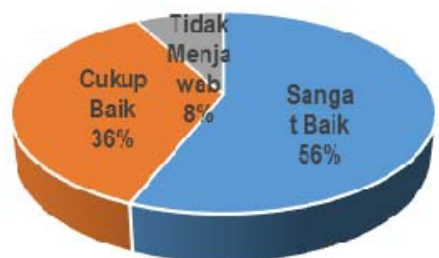

Gambar 11. Kualitas Metode Pengajaran oleh Fasilitator (Narasumber dan Tutor)

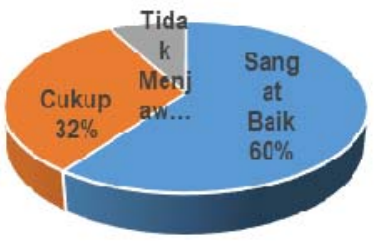

Gambar 12. Kinerja Penyelenggara Pelatihan 


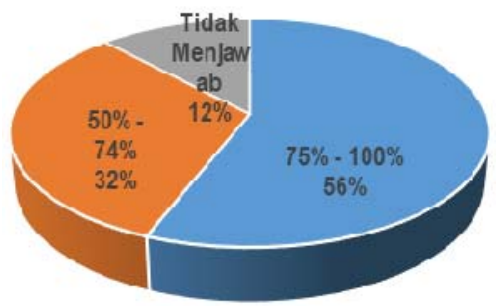

Gambar 13. Persentase Pemahaman Peserta

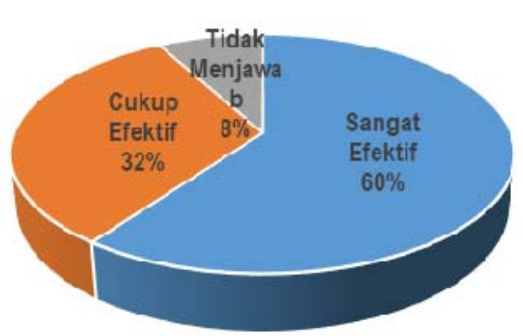

Gambar 14. Efektivitas Pelatihan

Berikut rangkuman hasil kuesioner dari kegiatan pelatihan hari ke 2. Secara umum peserta menyatakan kualitas materi pelatihan sangat jelas (59\%); teknik penyampaian materi sangat baik $(65 \%)$; dan kinerja panitia untuk pelatihan ini dinilai sangat baik (65\%). Sehingga tingkat pemahaman peserta akan e-commerce menjadi sangat baik ( $75 \%$ dari total peserta). Akhirnya $71 \%$ dari total peserta menyatakan pelatihan ini sangat efektif dan seluruh peserta tertarik untuk mengimplementasikannya setelah pelatihan.

\section{KESIMPULAN DAN SARAN}

Dari kegiatan pelatihan dapat disimpulkan bahwa kegiatan ini meningkatkan pemahaman peserta UMKM sehingga diharapkan mampu meningkatkan kapasitas UMKM Kota Denpasar, sekaligus meningkatkan kapasitas perempuan dibidang perekonomian online. Hal ini dibuktikan dengan hasil evaluasi kegiatan dimana $71 \%$ dari total peserta menyatakan pelatihan ini sangat efektif dan seluruh peserta tertarik untuk mengimplementasikannya setelah pelatihan. Efektivitas kegiatan didukung oleh kinerja penyelenggara pelatihan baik ( $82 \%$ dari total peserta), bahkan $60 \%$ menyatakan sangat baik, serta materi pelatihan dan kualitas pengajarannya lebih dari $90 \%$ menyatakan baik.

Kegiatan ini masih fokus dengan pemahaman Internet dan Pengenalan e-commerce yang memanfaatkan toko - toko online yang sudah ada dan transaksi dengan media sosial seperti Facebook dan Instagram. Untuk itu disarankan kegiatan berikutnya, yaitu (1) memperluas pelatihan dengan materi yang sama untuk peserta perempuan UMKM lainya di Denpasar atau daerah lain di Bali dengan tetap bekerjasama dengan pemerintah daerah; dan (2) memberikan pelatihan dengan topik lanjutan terkait e-commerce seperti transaksi keuangan, teknik keamanan transaksi, dan teknik promosi online untuk peserta yang sama.

\section{UCAPAN TERIMAKASIH}

Penulis mengucapkan terima kasih kepada:

- LPPM Universitas Udayana yang telah berkenan membiaya pengabdian ini melalui DIPA PNBP Universitas Udayana TA 2017, Sesuai dengan Surat Perjanjian Penugasan Pelaksanaan Hibah Pengabdian kepada Masyarakat Udayana Mengabdi Nomor: 674 - 65/UN14.4.A/PM/2017, tanggal 12 Juli 2017.

- BPPA (Badan Pemberdayaan Perempuan dan dan Anak) Dinas Pemberdayaan Perempuan dan Perlindungan Anak, Pengendalian Penduduk dan Keluarga Berencana - Pemerintah Kota Denpasar untuk bantuan dan kerjasama yang begitu baik dalam menyelenggarakan kegiatan ini.

\section{DAFTAR PUSTAKA}

Artikel Keamanan Tokopedia, 2017. https://www.tokopedia.com/panduan-keamanan/artikel-keamanan/, diakses 23 Juli 2017.

Bank Negara Indonesia, 2017. www.bni.co.id, diakses 12 Agustus 2017. 
Belanja Online Aman \& Nyaman - Jualan Online Mudah \& Gratis, 2017. www.tokopedia.com/, diakses 23 Juli 2017.

Belanja Online Aman, Nyaman, Terpercaya, 2017. https:/www.mataharimall.com/, diakses 29 Juli 2017.

Bhinneka Bisnis Lengkap, 2017. http://bisnis.bhinneka.com/, diakses 5 Agustus 2017.

Bhinneka.Com: Toko Online Komputer, Gadget, Fotografi, Elektronik, 2017. http://www.bhinneka.com/, diakses 5 Agustus 2017.

BI, 2016. Pemetaan dan Strategi Peningkatan Daya Saing dalam Menghadapi MEA 2015 dan Pasca MEA 2025. http://www.bi.go.id/id/umkm/penelitian/nasional/kajian/Pages/Pemetaan-dan-Strategi-PeningkatanDaya-Saing-UMKM-dalam-Menghadapi-Masyarakat-Ekonomi-ASEAN-(2015)-dan-Pasca-MEA2025.aspx

Bukalapak: Situs Belanja Online dan Jual Beli Mudah Terpercaya, 2017. https://www.bukalapak.com/, diakses 6 Agustus 2017.

BUMN, 2015. Kriteria Usaha Mikro, Kecil dan Menengah menurut UU no. 20 Tahun 2008 tentang UMKM. http://bumn.go.id/jamkrindo/berita/0-kriteria-usaha-mikro-kecil-dan-menengah-menurut-UU-no-20tahun-2008-tentang-UMKM

CNN Indonesia, 2016. Kontribusi UMKM Terhadap PDB Tembus Lebih Dari 60 Persen. https://www.cnnindonesia.com/ekonomi/20161121122525-92-174080/kontribusi-umkm-terhadap-pdbtembus-lebih-dari-60-persen/.

Collaborative Security: An approach to tackling Internet Security issues, 2017. https://www.internetsociety.org/collaborativesecurity?gclid=EAIaIQobChMIhKeDPrH1wIVSIC9Ch2jpA5QEAAYBCAAEgKfOvD_BwE, diakses 8 Juli 2017.

Ethics and the Internet, 2017. https://www.isoc.org/inet2000/cdproceedings/8k/8k_3.htm, diakses 8 Juli 2017.

GO-JEK Indonesia, 2017. https://www.go-jek.com/, diakses 6 Agustus 2017.

grab.com - Grab Taxi, Car, Bike \& Express - All In 1 Ride Hailing App, 2017. www.grab.com/Grab/Indonesia, diakses 6 Agustus 2017.

Kembangkan bisnis Anda dengan Lazada, 2017. https://www.lazada.co.id/jualan-online/, diakses 15 Juli 2017.

Lazada Security Contact Details \& Bug Reporting, 2017. https://www.lazada.co.id/security/, diakses 15 Juli 2017.

MatahariMall.com Help Center, 2017. https://help.mataharimall.com/hc/en-us, diakses 29 Juli 2017.

Mengapa berjualan di MatahariMall lebih menguntungkan?, 2017. https://www.mataharimall.com/static/5/sellwith-us, diakses 29 Juli 2017.

Oetomo, HR, 2017. Seribu Perempuan Pegiat UMKM di bali Bahas Digitalisasi Pemasaran.

http://www.rri.co.id/denpasar/post/berita/423664/ekonomi/seribu_perempuan_pegiat_umkm_di_bali_bahas_digi talisasi_pemasaran.html

Panduan Keamanan Tokopedia, 2017. https:/www.tokopedia.com/panduan-keamanan/, diakses 23 Juli 2017.

Rivera A., 2016. What is E-Commerce?. https://www.businessnewsdaily.com/4872-what-is-e-commerce.html

Shopee Indonesia 11.11 - Cashback \& Gratis Ongkir - shopee.co.id, 2017. www.shopee.co.id/, diakses 12 Agustus 2017.

Sulistyowati A. 2017. 6 Perempuan Pengusaha UMKM di Bali Gelar Pameran di New York, https://kompas.id/baca/nusantara/2017/08/13/6-perempuan-pengusaha-umkm-di-bali-gelar-pameran-dinew-york/.

The Initial Internetting Concepts, 2017. https://www.internetsociety.org/internet/history-internet/brief-historyinternet/, diakses 8 Juli 2017.

Toko Online Blibli.com, Sensasi Belanja Online Shop ala Mall, 2017. https://www.blibli.com/, diakses 13 Agustus 2017.

Zalora, 2017. https://www.zalora.co.id/sell-with-us/, diakses 15 Juli 2017. 